\title{
RECENZIÓK
}

\section{Bóna Judit(szerk.): „Friss térképpel a gyermeki beszéd világában” Új utak a gyermeknyelvi kutatásokban} Budapest ELTE Eötvös Kiadó 2017243 p. ISBN 9789632840024

Az ELTE Eötvös Kiadó gondozásában 2017-ben jelent meg Bóna Judit szerkesztésében az Új utak a gyermeknyelvi kutatásokban címü kötet, melynek létrejöttét az NKFI - Nemzeti Kutatási Fejlesztési és Innovációs Hivatal - támogatta. A kötet szerkesztője az Eötvös Loránd Tudományegyetem Bölcsészettudományi Karán a Fonetikai Tanszék oktatója. A könyv borítója friss üde színével kellemes benyomást kelt bennünk. A 243 oldalas kötet borítójáról két boldog, egymással társalgó gyermek képe néz vissza ránk. Mindez egyértelmüen utal a kötet témájára; a hátoldalon található rövid tartalmi összefoglaló még inkább megerősíti, mire gondoltak a cím megválasztásakor, mire utalhatnak az új utak. A tartalmi összefoglaló rávilágít: míg a beszédelsajátítás kezdeti szakaszát, valamint az iskolába lépéskor kialakult beszédkészségeket számos vizsgálat kutatja, és ismereteink ebből a két korszakból mondhatók a legszélesebb körünek, más korszakok elhanyagoltnak látszanak. A kötet foglalkozik a gyermeknyelvi adatbázisok felhasználási és kutatási lehetőségeivel, az eddig kevésbé vizsgált életkori csoportok nyelvelemzésével, új kérdések és megközelítések alkalmazásával a gyermekkori nyelvkutatás területén, valamint külön kiemeli a kötet szerkesztője, hogy egy új, Magyarországon innovációnak tekinthető módszertan is bemutatást nyer a kötetben. Hangsúlyozza, hogy a kötet nem csupán az elméleti alapok növelésére szolgál; az egyes életkorokban megjelenő nyelvi sajátosságok ismerete kiemelt jelentőséget kap a gyakorlati alkalmazásban is. A tanulmányokban vizsgált kérdések további kutatása pedig újabb tanulmányok és vizsgálati eredmények megszületéséhez is alapot adhat.

A kötetben 11 tanulmány található. A szerzők jobbára az Eötvös Loránd Tudományegyetem Bölcsészettudományi Kara Fonetikai tanszékének munkatársai, ugyanakkor többen a Magyar Tudományos Aka- 
démia Nyelvtudományi Intézetének tudományos munkatársai, egy szerző pedig a Budapesti Műszaki és Gazdasági Egyetem (BME) Távközlési és Médiainformatikai Tanszék oktatója.

A tanulmányokat olvasva meggyőződhetünk arról, hogy tudományosan alapos, hivatkozásaiban is pontos szakmai könyvet tartunk a kezünkben. A jól tagolt, részletes, könnyen értelmezhető ábrákkal kiegészített tanulmányok végén alapos, részletes szakirodalmak jelzik, a további információk keresésekor is számíthatunk a szerzők széleskörü és alapos szakirodalmi tájékozottságára mind a magyar nyelvü, mind a külföldi - és ezen belül nem csupán angol, hanem néhány esetben francia nyelvü - források esetében. A források elérhetőségének megkönnyítése érdekében számos esetben feltüntetik a szerzők azok internetes lelőhelyét is - így akár néhány kattintással és némi idegennyelv-ismerettel mi magunk is elmélyedhetünk azoknak a külföldi kutatóknak a munkáiban, akik a szerzők számára is forrásul szolgáltak. A magyar nyelvü források között megtalálhatjuk a több évtizedes köteteket éppúgy, mint az alig néhány hónapos publikációkat. A friss szakirodalmak mellett ez esetben is weboldalak címe segít abban, hogy érdeklődés esetén mi magunk is elolvashassuk azokat. Ahogy a kötet hátoldalán a szerző is leírja, a tanulmányok három különböző típusba sorolhatók. Az első csoport célja az eddig megtörtént kutatások eredményeinek összefoglalása, eddigi ismereteink rendszerezése. Ebben a fejezetben a gyermeknyelv kutatásának rövid, ám a régebbi időkbe is visszanyúló eredetébe nyerhetünk betekintést. Már Arisztotelész is alkotott elméleteket a gyermeki beszéd és az emberi psziché összefüggésiéről. Az elméletek mellett a módszerek is rendkívül sokat változtak az évszázadok során. A második csoportba azok a tanulmányok sorolhatók, melyek elkészülésük közben vagy témájuk alapjául a GABI - Gyermeknyelvi adatbázis és információtár - adatbázis-információt használták fel, ezáltal a kvantitatív elemzési móddal megerősítve elméleteiket. Az adatbázisnak, mely az ELTE BTK Fonetikai Tanszékén készül, célja, hogy különböző életkorú gyermekek köznyelvi beszédét rögzítse. A harmadik csoportba a szerkesztő ajánlása alapján is az az egy tanulmány kerül, mely egy hazánkban eddig új nyelvelemzési módszerrel ismeretet meg minket. A Magyar Tudományos Akadémia és az ELTE közös programja során a beszédartikuláció orvosi vizsgálattal történő vizsgálatára hazánkban eddig még nem volt példa.

A kötet olvasása előtt, pusztán a tartalomjegyzék alapján magam is úgy véltem, hogy a tanulmányok ezen három csoport alapján majd szigorúan elválaszthatóak lesznek egymástól, és a három téma alapján kizárólag a saját csoportjuk témakörével foglalkoznak. A figyelmes olvasás alapján 
azonban úgy tünik, a tanulmányok, egymásra is hivatkozva, mintegy hálózatszerűen kötődnek egymáshoz. Mindez nem is lehet véletlen: hiszen csak az eddigi munkákat megismerve, számos vizsgálatot lefolytatva juthatunk el az innovációs fázishoz.

Mindez azonban nem jelenti azt, hogy a kötet csak az első betütől az utolsóig, szigorú sorrendben olvasható. A tanulmányok természetesen önállóan is mind megállják a helyüket, így könnyen tudunk belölük szemezgetni érdeklődésünknek megfelelően.
A kötet végére érve megállapíthatjuk, hogy felhasználása mind a kutatók, mind a gyakorlati szakemberek, sőt akár a szülők hasznos olvasmánya is lehet. Előbbi csoport számára megkönnyítheti a fontosabb szakirodalomban fellelhető eredmények összefoglalását, új kutatási kérdések fellelését; a pedagógusok számára a gyakorlati életben felhasználható ismeretek lehetnek érdekesek, a szülők számára pedig segítséget jelenthet gyermekük családi körben történő beszédelsajátításának elősegítése és megerősítése érdekében.

NÉMETH DÓRA Katalin ${ }^{1}$

\footnotetext{
${ }^{1}$ Neveléstudomány MA-szakos hallgató, Debreceni Egyetem Bölcsészettudományi Kar Nevelés- és Müvelődéstudományi Intézet; nmthdr@gmail.com
} 